\title{
DRUMMERS OF THE SULTAN OF BUTON: \\ THE LASTING INFLUENCE OF THE DUTCH EAST INDIA COMPANY ON LOCAL MUSIC TRADITIONS
}

\author{
Miriam L. Brenner
}

Bau Bau, 2007

In 2007, while doing my Bachelor of Arts in musicology, I chose to do fieldwork in a faraway place, gathering my own field data, and above all having a firsthand experience of music in context. I was fascinated with Indonesia and after listening to the $20 \mathrm{CD}$-series of Indonesian music recorded by Philip Yampolsky for Smithsonian Folkways I got in touch with him. He introduced me to Bandung-based musicologist Endo Suanda and his Tikar Media Budaya Organisation, ${ }^{1}$ and together we decided to carry out research on the music of one of the most 'unrecorded' areas in the archipelago: Southeast Sulawesi. We narrowed down the scope of my fieldwork somewhat and decided to make an inventory of the music of Buton and its surrounding islands, and to what later proved to be my encounter with a rich drumming tradition. While Buton had rarely been visited by researchers, I was not the first to have paid attention to its musical traditions. In fact, my own experience could be placed in a genealogy of musical encounters in which visitors from elsewhere had come into contact with local musicians; encounters which obviously left their mark on some of the islands' musical traditions.

In this chapter I will focus on several of such historical encounters with the music and musicians of Buton, starting with the first interactions between the VOC and the inhabitants of the island in the sixteenth century, moving on to the account of Swedish ethnographer Walter Kaudern, who in 1927 (80 years before my own encounter) wrote a book on the musical culture of Sulawesi. In his book Kaudern also briefly touches upon the 'Drummers of the Sultan of Boeton'. Furthermore, in 1937 government linguist Van den Berg described some of Buton's musical richness, making

\footnotetext{
1 Suanda was the project director of the local partner organization that was founded specifically for this recording project; MSPI (Masyarakat Seni Pertujukan Indonesia). 
explicit mention of the very same drummers of the Sultan and the flag his guards carried along in procession, which resembled the splendour and might of the former Dutch East Asia Trading Company (VOC). The last of these encounters then is my own visit in 2007.

Aside from describing how this peculiar drumming tradition has transformed over time, I will explain which aspects of Dutch imperial tradition were mimicked, musical or otherwise. I will begin with Homi Bhabha's (2005) concept of 'spheres of activity', coined in 1994, referring to those cultural aspects through which the colonizer can exert its power, with music being one, though often neglected domain. How has the musical sphere functioned in processes of Othering, both on the side of colonizers and the colonized? Which musical features have been selected to do so, and which ones have been left out? And, most importantly, what may have been the primary drive for Butonese musicians to adopt imported musical elements? Before getting to these questions and the encounters from which they arose, let me first introduce some of the islands musical richness.

\section{Buton Island, a Musical Context}

The Isle of Buton, located off Southeast Sulawesi's coast, is strategically positioned between the port city of Makassar and the spice islands of Maluku. The islands situated off the coast were deemed important to the Southeast Asian maritime trade and, consequently, became part of an ongoing power struggle (Evers 1988; Evers and Heallquist 1991). Until the 196o's, Buton was also the centre of the Kingdom of Wolio, its capital being the city of Bau Bau, from where a sultan had ruled over the surrounding islands of Muna, Kabaena and the Tunkang Besi Islands.

In 1542, Buton became a Sultanate when Buton's sixth monarch, Raja Mulae - Sultan Murham came to power (Pigeaud 1960: 17). The Sultan had converted to Islam under the influence of Abdul Wahid who, according to local tradition, brought the religion to the island (Zahari 1977, I:46, 1980:40). Other sources mention the implementation of Islam in 1580 under the rule of Ternate Sultan Baaboellah, although it is clear that some of the inhabitants were already practicing Islam by that time (Ligtvoet 1878: 31; Schoorl 1986: 1). Other Arabic elements subsequently found their way to the islands, including novel musical elements.

Much of the commonality between instruments in the region can be explained by having a closer look at centuries of trade and ongoing power struggles within the region. Gong chimes and bamboo instruments are found throughout Sulawesi, Borneo, the Moluccas and the Philippines 
(Maceda 1998; Hilarian 2003). From the 13th century onwards, when the Buton area was subjugated by the Majapahit Empire, and its monarchy presumably came under Hindu-Javanese influence (Schoorl 1986: 1), Javanese gong makers are thought to have introduced their craft to the island. Other instruments, as well as forms of poetry that still feature prominently in Buton's music life, similarly originate from a foreign source and thus clearly reflect the islands socio-economic and religious past (Brenner n.d.). In the aftermath of the introduction of Islam, the frame drum ganda maludu ${ }^{2}$ was introduced, named after the celebration of the birth of the Prophet Muhammad (Mawlid an-Nabì), one of the primary ceremonies it was used in. In addition, the Sultan's prominent position and the musicians' affiliation to his kraton (the residence of the Sultan and his court dignitaries $)^{3}$ explain one of the most iconographic forms of music, which will be discussed below. Lastly, from the initial arrival of the VOC, the Dutch presence has had a lasting impact on Butonese music. Influences range from the self-styled bamboo versions of foreign brass instruments, a practice more commonly found throughout Southeast Asia (Boonzajer Flaes 1993: 48-49), to the tradition of the so-called o-ore buzzing wand that today is a regular feature of diatonically-tuned ensembles. However, this chapter focuses more specifically on the tamburu drum, which is mainly played during (military) processions, and can be considered the most obvious foreign influence on the island.

\section{Sixteenth Century Contacts}

Schoorl (1986: 27) describes how The Netherlands considered itself to be 'master' of Buton and territories as far back as $1776 .{ }^{4}$ Initially, the Dutch presence had been in name of The Dutch East India Company that first arrived on the island in 1612. At that stage, sovereignty over Buton was disputed by the Sultanates of Ternate and Makassar, but its strategic position had not gone unnoticed by Dutch Governor-General Both. In order to

\footnotetext{
2 In other parts of the archipelago the ganda maludu or gendang maulid is referred to as rabana or kompang.

3 Much of the former Sultanate's hierarchical subdivisions still exist today, in spite of the Sultanate having being dissolved in the 196os. Of the four existing social strata, two resided within the Kraton. This was the Sultan and his relatives (the so-called Kaomu) and the members of parliament and their families (the Walaka) (Fontijne 1949). This system was overthrown during Japanese occupation, disrupting social, economic and political life in the area (Madleven et al. 1947/48).

4 See also Ligtvoet (1878: 84, 105); Rudyansjah (2009).
} 
secure a monopoly over the spice trade, Both ordered his troops to 'ally' with the Butonese, to ward off the Makassar and other competitors in the region. He also got the Butonese to agree to a prohibition on growing certain crops and spices themselves for which they were to receive compensation (Kielstra 1908: 465). Sultan La Elangi (1597-1633), fearing Makassar's aspiration to expand, signed a treaty in 1613, thus ensuring protection by the VOC (Kielstra 1908: 465). La Elangi and his people made a favourable impression on Pieter Both, who wrote to his commanders about their good manners and wit (Tiele 1886: 34-35). Unfortunately, not everyone shared Both's sense of urgency to be based in Buton and bring in troops for protection, often leaving the Butonese at the hands of the Makassarese. As a consequence, one of Buton's prime dignitaries, the sapati, decided to defect and join these very same Makassarese. It was with this background of increased animosity between different parties, that the Butonese would first hear the sounds of Dutch military music.

Three years after the court city (kraton) in 1634 had been fortified and the first hostilities had taken place, the new Governor-General Van Diemen arrived in Buton demanding retaliation money. The Butonese did not comply and further hostilities were inevitable. After initial success withstanding the Dutch, the Butonese could not cope with a second siege of their city. Eventually they were defeated due to intelligence provided by locals (Schoorl 1991: 35). Van Diemen's report of his victory is the earliest account of European drums sounding over Buton. He refers to their prominent role in the battle:

And our braves - with flags flying and drums beating as they should marched alongside the city at the foot of the mountain to look for suitable access, intimidated the enemy so, that no one dared to show themselves outside of the city (see Tiele 1886: 337 ). ${ }^{5}$

Likewise, the intimidating effect of the drums must have impressed the Sultan who decided to use the instruments to his own advantage to frighten others.

Originally, Western drums were more than just musical instruments, gaining much of their importance from the military context in which they were initially embedded. Along with other instruments such as cymbals

5 Translated from the Dutch '[...] ende heft de couragie van d'onse, die in geode ordre met vliegende vaendels endo trommelslgh, opden voet des berghs, langhs de stadt marcheerden, omme bequaem acces te soecken, den vijant sulx g'intimideert, dat sich niemant buyten de stadt dorste verthoonen [...]'. 
and horns, drums were implemented in European military companies, after seeing how they had been used by Turkish military bands in early Ottoman times. In an Asian context, drums were used not only in battle but also in military processions for both formal and informal occasions. They helped maintain a consistent marching pace, they could signal what to do, but they also struck fear in the hearts of the enemy, impressed and intimidated. The Sultan's choice to mimic European drum patterns seems to have been based on their awe-inspiring potential in particular.

In the mid-seventeenth century, all Sultanates east and west of Buton surrendered to the Dutch East India Company and the 'Pax Neerlandica' was established. From this point onwards, the Sultanate of Buton would be appointed with a local ruler to exercise 'self governance'. However, the Dutch presence would be continuous and in reality the Sultan's power was reduced to that of administrative status only (Ligtvoet 1878: 31; Kielstra 1908: 452-465).

\section{Kaudern's 1920s Quest through Celebes}

After its bankruptcy in 1798, all VOC lands were declared to belong to the new Dutch National Colony. But while the Dutch would be present in the region for almost 300 years, it was only from 1906 onwards that intervention in all spheres of activity would become manifest and an objective in itself. Although in name still self-governing, Buton would from then on become part of a colonial system. Schoorl (1986:2) comments upon how, in this period, the foundations were laid for an entirely new system. Whereas there is substantial literature on the first military and economical interests in Buton - often written by Dutch administrators, VOC officials or missionaries - accounts that deal with this transformative period starting in the late-nineteenth century are far fewer in number (but see Martin 1894).

Things changed with the publication of a 1927 book that deals with the musical instruments in what was then still called Celebes, and which is written by Swedish ethnographer Walter Kaudern. Kaudern described only two musical instruments for the area of Buton: a double clarinet and a drum. ${ }^{6}$ Minimal explanation is provided by the Swedish ethnographer, but one of the photographs included (image 5.1) is telling as Kaudern (1927: 138) states:

${ }^{6}$ Only evidence of the latter could still be found during my own visit in 2007. 


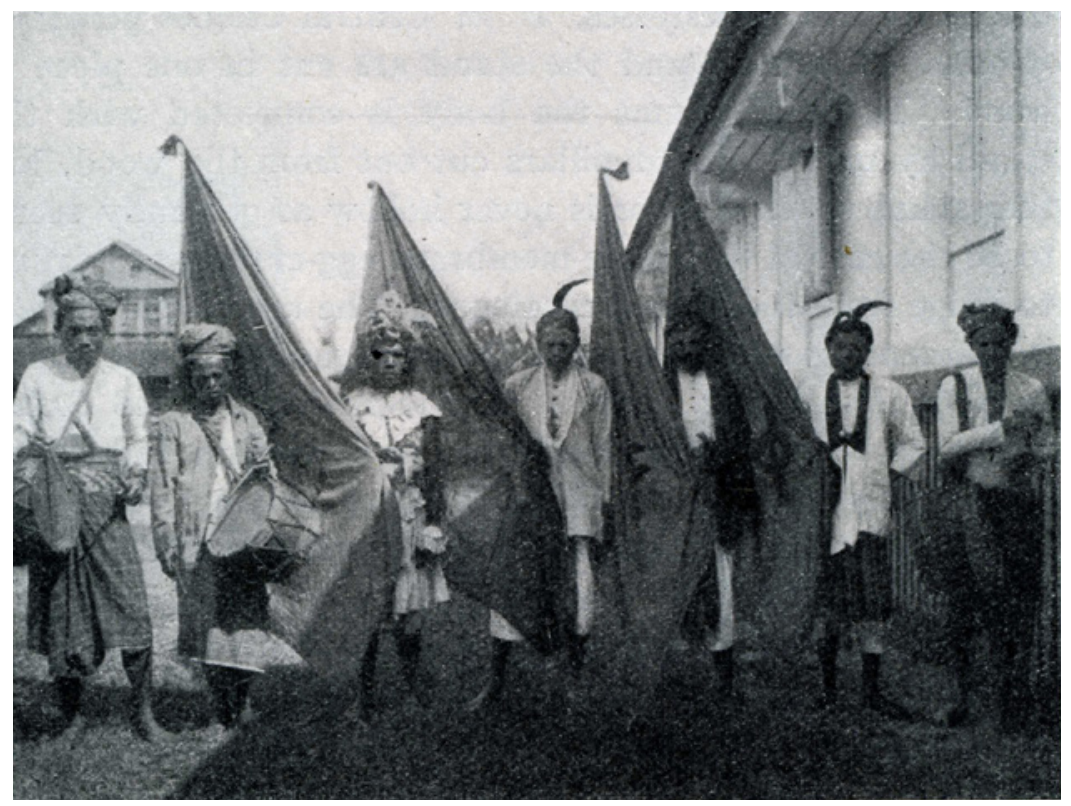

Image 5.1 Drummers of the Sultan of Boeton by Walter Kaudern (1927).

In [this figure] are represented the drummers of the Sultan of Boeton with their instruments. They are of European pattern, presumably relics from the sixteenth and the seventeenth century when the Dutch East India Company ruled the Malayan Archipelago. The bracing of the membranes is that of the old European drum [...].

Mention of the Company seems to suggest that what we are dealing with is a military drum, and one that is often referred to as a 'field' or 'guard's pattern drum'. Generally, such instruments consist of a cylindrical wooden shell, the height of which is slightly greater than the diameter. Both ends are covered by a membrane made from animal skin and tensioned on a ring. Indeed, the black-and-white photo entitled Drummers of the Sultan of Boeton seems to prove this as it shows three European-style cylindrical drums with a method of rope lacing that is characteristic of military drums. The Sultan's drums are worn on one side, hanging from a shoulder strap, and appear to have been influenced by what is known as a 'side drum'. ${ }^{7}$

7 It can be argued that it is both a formal as well as an informal feature, since the position is a stylistic part of the uniform, but in practice it is worn this way for technical reasons. 
Less discernible on this photo are the long, thin sticks held by the drummers, which seem to echo European drumsticks. Nothing is documented on the rhythms and if they were of European derivation, but if they were quick and consisted of meticulous ruffles, one indeed needed such European sticks. One may wonder to what extent these musical details were copied from the colonizer. Image 5.1 shows seven men standing in a row, separated by upright flags. They wear a variety of headdresses, clothing and are holding several objects in their hands. Three men wear a turbantype headdress; three others have extra-fabric ornaments and one other type of headdress is also shown. Four flags and three drums are accounted for, but the four men are not uniformly dressed. At least the most important element in the photograph - the drum - is consistent in appearance, since all the turban-wearing men carry a drum. Are these the same drums that intimidated the Butonese back in 1637, when Van Diemen attacked the city? Are the flags reminiscent of VOC times? And what is the function of these men in the photograph whose attire seems to imitate that of the former colonizer?

\section{Van den Berg's 1930 Visits to the Kraton and Beyond}

E.J. van den Berg (1908-1942) was born into a missionary family on the East coast of Sumatra. His father was an authority on the Karo-Batak language (Cense 1954: 154). From 1937 Van den Berg spent four years as a government linguist at the court of Buton, during which time he produced meticulous notes on the culture and customs of the Bau Bau Kraton. Unfortunately, most of these notes were destroyed during World War Two, but part of them were published before the war started and may tell us something of the everyday and, in particular, the musical life of the kraton.

While studying ceremony at the kraton, Van den Berg witnesses similarly clad men as Kaudern had done previously. In one of his publications, Van den Berg (1937: 658) explains the functions of these men and their costumes in more detail after observing a celebration of raraja hadji:

At the opening of such a dance the alifirisi elegantly waves the flag and whereupon he dances simple steps with the loetoenani. The alifirisi holds the wooden flagpole in one hand, while holding the flag itself in the other, so it cannot dangle during the dance. The loetoenani produces several swinging movements with his gala [...]. The saraginti's do not dance, yet remain in formation close to the dancers while holding their sapinggara's. While 
playing the drum the tamboeroe's take a few dance steps as well. After the dance, the alifirisi continue waving the flag (Van den Berg 1937: 659). ${ }^{8}$

During a sultan's procession, tamburu drummers, as Van den Berg calls them, are always accompanied by flag bearers (alifirisi) and spear bearers (letunani). The latter a two, are dancers. But how does this relate to Kaudern's photograph? Some of these men are also clearly depicted in image 5.1, with additional men presumably being the saraginti, or Sultan's bodyguards. ${ }^{9}$ These are the more formally dressed figures depicted in the right half of image 5.1. with a sickle ornament on their headdresses. The men depicted in images 5.2 and 5.3 , taken some ten years later, seem to have long hair, although Van den Berg (1937: 657) describes them as having a wig, part of a dancer's regular attire. The tamburu seem to refer to the 'tamboer' drummer, or 'tamboer-majoor' drum-major. This 'tamboeroe drum' is described by Van den Berg (1939: 488) as a 'wooden drum of rather common type, on which two drumsticks are struck'. ${ }^{10}$

Despite the lack of proper knowledge about which rhythms were played, something can still be reconstructed from Van den Berg's remarks on the tamburu. They were played while hung from a shoulder or strapped around the waist and could be identified by 'het roffelen der trommels', 'tromgeroffel' and 'op de maat van de trommelslagen' (Van den Berg 1937: 658-659, 1939: 488, 496, 504). The words Van den Berg uses (respectively: the roll of the drums, drum roll, and the beat of the drum) are illustrative as they seem to refer to the characteristic rhythms and timbre of military or snare

8 Translated from the Dutch: 'Bij het begin van een dergelijke dans zwaait de alifirisi eerst op sierlijke wijze het vaandel en danst vervolgens met den loetoenani eenvoudige danspassen. De alifirisi houdt den vlaggestok in de eene hand, en de vlag zelf in de andere, zoodat zij onder den dans niet kan uitzwaaien. De loetoenani maakt onder het dansen ook eenige zwaaiende bewegingen met zijn gala [...]. De saraginti's dansen niet, doch blijven staan in de nabijheid der dansers opgesteld met hun sapinggara's in de hand. De tamboeroe's maken onder the trommelen ook eenige passen. Na afloop van den dans zwaait de alifirisi weer met het vaandel'.

9 Kielstra (1908: 465) describes how planting certain crops, such as nutmeg, were prohibited but that the Sultan received compensation in return. In 1824, this resulted in an allowance to the Sultan, including the assignment of soldiers as honorary guards, possibly the Saraginti bodyguards.

10 The word 'tamburu' is translated in Anceaux's dictionary (1987: 176) as a 'Western type (army) company drum'. The tamboeroe-type drum, therefore, must have been recognizable to the Dutchman as a 'general instrument' and, we can conclude, was not an indigenous object. I conclude, therefore, that it must also be the same drum in Kaudern's photograph, which he speaks of as being a 'drum of European pattern'. 


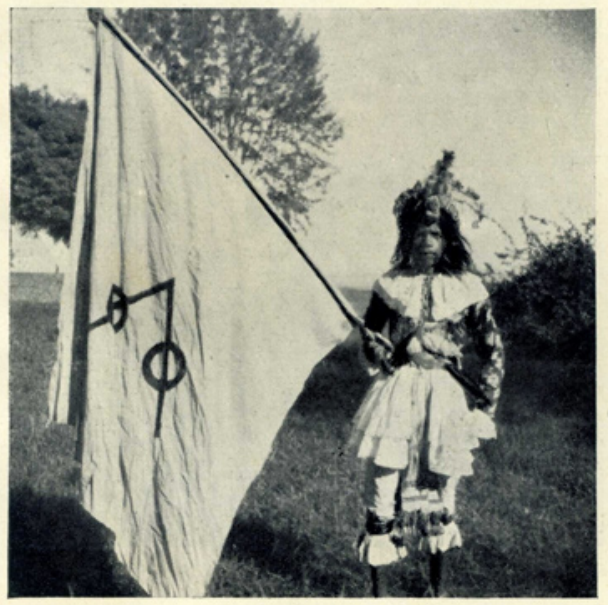

11. 'Alifirisi (p. 527).

Image 5.2 Alifirisi by Van den Berg (1937).

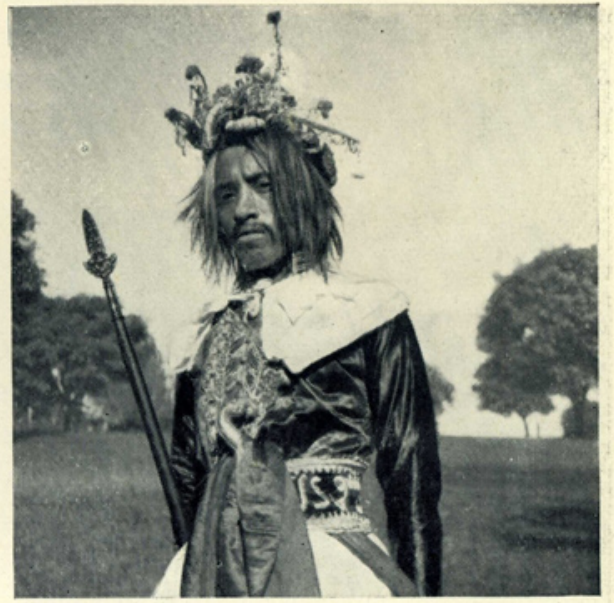

10. Detail van afb. 9.

Image 5·3 Loetoenani by Van den Berg (1937). 
drums. ${ }^{11}$ Within a ceremonial context, three extra musical features are further highlighted by Van den Berg, who states that a) the drums are played during a procession, however short it is; ${ }^{12}$ b) they are played when the Sultan's insignias are collected and shown to him (Van den Berg 1939:496); and c) these drums are played at specific moments during the procession, when, according to adat customs, an honorary dance must be performed to the beat of the drums (Van den Berg 1937: 659, 490). ${ }^{13}$

The dance observed by Van den Berg does not give an impression of being a combat dance, even when the letunani swing their spears around. Nevertheless, the performance may be reminiscent of a war dance once meant to intimidate and enforce respect. The military connotation of the drums in this ceremony seems to signal such a function and so are the assigned ranks and the overall military character of the performance troop. Van den Berg (1939: 470) writes: 'Loetoenani, Alifirisi, Tamboeroe, four Saraginti's: these men form one of the eleven kompanjia's, of which five belong to the Sultan [...].'14 The word kompanjia is obviously derived from the Dutch compagnie, and originates in French military terminology, meaning 'a subdivision led by a captain' (Van der Sijs 1994: 72). The words saraginti and letunani have similar military resonances and can be linked to the ranks of sergeant and lieutenant. Alifirisi (according to Van den Berg, situated between the previous two in rank order), is possibly a local rendering of the Portuguese alpérés, and refers to a rank below a lieutenant (Zahari 1977; Stevens and Schmidgall-Tellings 2004: 26). Anceaux translates it as a warrant officer, enlisted to the former Butonese army

11 Taking into account his detailed writings, which include a description when a previously unknown instrument is mentioned, it is safe to assume that he would not use such terms for an indigenous rhythm. During the Sultan's initiation ceremony within the Kraton walls, eight different dala rhythms are played. They are not referred to as 'common' or 'tromgeroffel', implying explicitly that European rhythms have not been implemented in this traditional ceremony.

12 Van den Berg (1939: 490) also describes how during this walk of only a few minutes the drums of some kompanjias sounded, while having arrived at the palace the Loetoenanis and Alifirisis danced for a long time.

13 Translated from the Dutch: 'dan wil de adat, dat zij als eerbetoon een dans gaan uitvoeren, op de maat van de trommelslagen' (Van den Berg 1937: 659).

14 From these observations, we may conclude that Kaudern's photograph seems orchestrated and misrepresents the actual kompanjia structure. This is usual for colonial photography (see the contribution in this volume by Ouwehand). Four flags reflect four alifirisi and, subsequently, four full kompanjia (numbering a total of $21 \mathrm{men}$ ) according to the kompanjia's set up. But only eight men are present in fig.1. For each kompanjia group there is one bodyguard (saraginti), plus one. Three saraginti stand in the line, without their signature hooked spear. Only one dancer is present, and presumably the letunani is missing here. 
(1987: 2). These kompanjia, then, are a sphere of activity that has been clearly impacted by colonial presence, with names and ranks mimicking those in the European military system.

There is one other occasion on which the tamburu is beaten. The military drum makes one (albeit very brief) cameo appearance within a ritual that is often inserted between processions. This orchestral composition very much resembles, if we are to believe Van den Berg (1939: 488), one that was usually performed at the installation of the Sultan:

The Pata Limbona and some other dignitaries also took a seat inside the tent, where they listened to a small orchestra consisting of two drums, both double membrane of slightly conical form, two gongs (mbololo) and a tamboeroe [...]. [...] Eight different rhythms (dala) were played, and to this repertoire the Pata Limbona would listen. After finishing all eight rhythms, the Pata Limbona returned home but the orchestra had to continue playing all night, with the exception of the tamboeroe (Van der Berg 1939: 488). ${ }^{15}$

As this ritual takes place within the procession, the drum may have been included for rhythmic reinforcement. Since the tamburu do not participate further after playing the rhythmic sequences and do not take part in playing dance music, we may conclude that the tamburu is not a regular member of the cast. There are no further sources to even indicate the tamburu was or is used for other purposes than the procession or this rhythmic ritual. Although the tamburu has clearly taken root in the Butonese processions, its use is likely to have been restrained to playing within a processional context, whether during the dance, while walking, or while presenting the Sultan's insignias during an initiation ceremony. Typical of these customs and ceremonies of the Sultan is the playing of a series of specific rhythms or sequences (dala). Van den Berg described how the tamburu was included in the regular ensemble during such an initiation service. In terms of construction, the tamburu remain very different from other traditional instruments, including other Butonese drums.

What happened to the Kingdom of Wolio in those centuries after the Pax Neerlandica was established? After a period of self-governance, the

15 Translated from the Dutch: 'De Pata Limbona en eenige andere waardigheidsbekleeders namen ook binnen de tent plaats, waar zij luisterden naar een klein orkest bestaande uit twee trommen, [...] twee gongs (mbololo) en een tamboeroe [...]. Er werden acht verschillende rhythmen (dala) gespeeld, en naar dit repertoire bleven de Pata Limbona zitten luisteren. Toen de acht dala eenmaal afgewerkt waren, gingen de Pata Limbona weer naar huis terug, doch het orkest moest den gehelen nacht blijven doorspelen, uitgezonderd de tamboeroe'. 
Sultan's authority increasingly diminished and in 1906, following the signing of a mutual treaty, the Dutch were officially empowered to intervene in all of Buton's internal matters. The Dutch power play, from VOC times onwards, was presumably not only despised but also admired by the Butonese, which perhaps explains why its splendour and ceremonial display was incorporated into the little true authority the Sultan still had left; the power to impress in the realm of performance and spectacle. Thus, at a time when the Dutch East India Company was long declared bankrupt, Van den Berg (1939) could report how the dancers' or soldiers' attire seem to have been copied in meticulous detail from those worn in the times of the Company, as were other details of the procession. The uniforms in the procession consisted of 'fancy shirts with tight fitting jackets and were almost that of the VOC, as was its flag'; a yellow flag similar to that carried by Van Diemen's troops in 1637 and now used by Butonese dancers as Van den Berg (1937: 504) observes elsewhere (see image 5.3). ${ }^{16}$

\section{My 2007 Bau Bau Visit}

The 1906 contract between the Dutch and the Butonese 'was one (more) step towards the complete integration in the social system of the Indies', Schoorl wrote in 1986. Fast forward to 2007, when I set out to do my own fieldwork on Buton: It has been over half a century since the Sultanate was discontinued, following the passing away of the last ruler in the 1960 . Sulawesi officially became part of the Indonesian Republic.

Although the Sultanate's days ended over a century ago, present day kraton residents can still remember some of its former splendour. They were also able to point out what was happening on the photos made by Kaudern that I showed them, thus providing additional information on the Drummers of the Sultan of Boeton. So, for example, I learned that the head gear worn by the three men are named kampurui and are only supposed to be worn by the tamburu drummers, whereas the individual wearing what is called a kalu headdress is supposedly a dancer (Alifirisi or Letunani), judging from the uniform he wears.

Interestingly, in 2007 there was still one group of people who occasionally dress as depicted in Kaudern's photos. It is a dance group affiliated to the officially dismantled kraton that performs the traditional galangi dance. The galangi and the procession it was originally part of enabled

16 'The Alifirisi all carry a flag, of which four are yellow of colour, fitted with the emblem of the VOC (in red)'. 
the Butonese to re-establish local hierarchies. These ceremonies were vital in retaining the sense of a common ruler and the religious health of the inhabitants. The group leader explains that there is more to their appearance: 'It might seem as if the dancer has long hair, but actually,' he says, 'these are fibers from the pineapple plant'. The pineapple is a symbol of the Kraton of the Sultanate of Wolio. Although absent from the flags described by Van den Berg, wearing its fibres was a sign of respect and loyalty to the Sultan. Both Alifirisi and Letunani, in images 5.2 and 5.3, are wearing such a symbol emanating the power of the Sultan.

Practices seem to differ little from those described by both Kaudern and Van den Berg 70 years ago, and some of the elements performed here seem to echo a 400 year old past, from Company times onwards. The dancer's still wear kalu with pineapple-fibre wigs; their shiny, colourful shirts are decorated with a broad, white lace collar. When the alifirisi brings out his flag (see image 5.4), it is still a yellow one, but now the VOC emblem is absent. ${ }^{17}$

No new sultans have been installed after the inclusion of Sulawesi into the Indonesian Republic, making the raraja hadji initiation ceremony obsolete. With discontinuation of the sultanate a cultural manifestation is on the wane, and we lose a performing art, an expression of local identity and a platform for the tamburu to beat their drums. Fortunately the Galangi dance remains. The Wolio Dictionary describes the galangi as a 'kind of war dance' (Anceaux 1987: 36), the word itself being derived from the Wolio word gala, meaning 'spear'. The spear dance is mostly performed by the letunani, who function as the spear bearers. Today, the galangi has lost much of its warrior-like spirit and is mostly used in processions as to pay homage to high ranking officials.

But what about the drum itself, once being played by the Sultan's musicians? From my 2007 fieldwork, it soon became clear that the tamburu is not often played anymore, unlike other drums present on Buton and neighbouring islands. ${ }^{18}$ Very few old tamburu are conserved in Bau Bau

17 The Alifirisi is not wearing a pineapple headdress, because one could not be made in such short notice. Neither is the lace collar displayed, because it had to be ironed properly, which could not be done at that time.

18 Most common are the double membrane cylinder drums ganda and the double membrane, cylinder drum ganda dimba. The latter has two membranes, which differ in diameter, producing different tones, explaining the instrument's name dim-ba (Mekuo 1977/8). The manner of bracing in both drum types, points to an important discrepancy. The membranes of the larger ganda dimba are kept in place by (and tuned with) large pegs. In case of the ganda, both membranes are rolled around hoops, connected and tensioned by rope. Dimba are utilized during the seven-day bridal initiation ceremony Posuo and in dance accompanying ensembles. 


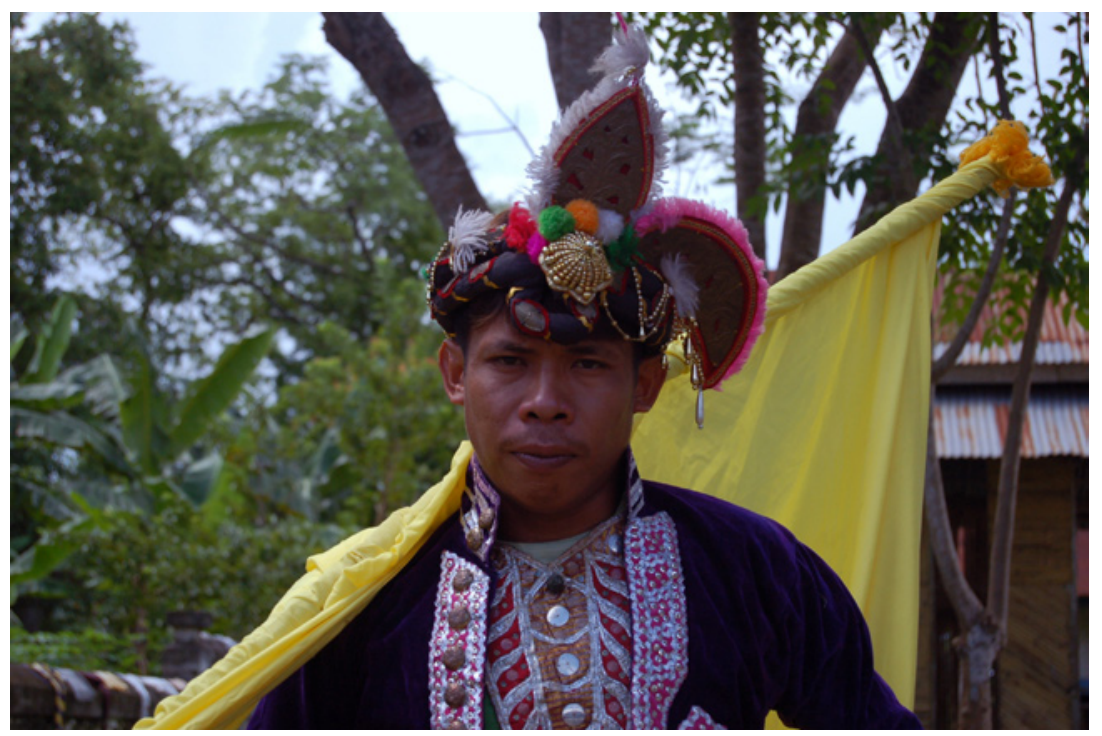

Image 5.4 Alifirisi in Bau Bau Kraton (photo by author, March 2007).

today. Fortunately, I found one that was owned by the galangi group's leader. From this drum we can learn that the tamburu's cylindrical body was once made from wola wood. The shell is reinforced by hoops on the inside and an air hole is drilled halfway for resonance. Both of the drumheads' membranes are rolled around a rattan ring, and its goatskin dried and torn (see images 5.5 and 5.6). ${ }^{19}$ The manner in which this old drum was constructed, confirms Kaudern's 1920s statement that the bracing of the Sultan's drums is similar to that of old European, perhaps Dutch, military drums. However, such drums have not been assembled for years, maybe even decades. Due to its complex manufacturing process, particularly in terms of putting the skins and the rattan ring in place, traditional membranes have now been replaced by factory-made versions. Presently, all tamburu consist of wooden shells covered by synthetic drumheads and include snares on the bottom, a previously unknown practice (see images 5.7 and 5.8) (Zahari 1977). By adapting to modern standards and seeking for new contexts the tamburu continues to be part of the Wolio culture.

19 Two wooden hoops of this extant drum (30 $\mathrm{cm}$ in diameter and $3 \mathrm{~cm}$ wide) show ten holes at one third the width, to enable the lacing. Colour variations where the hoops used to be attached to the body, are visible on both ends of the shell. 


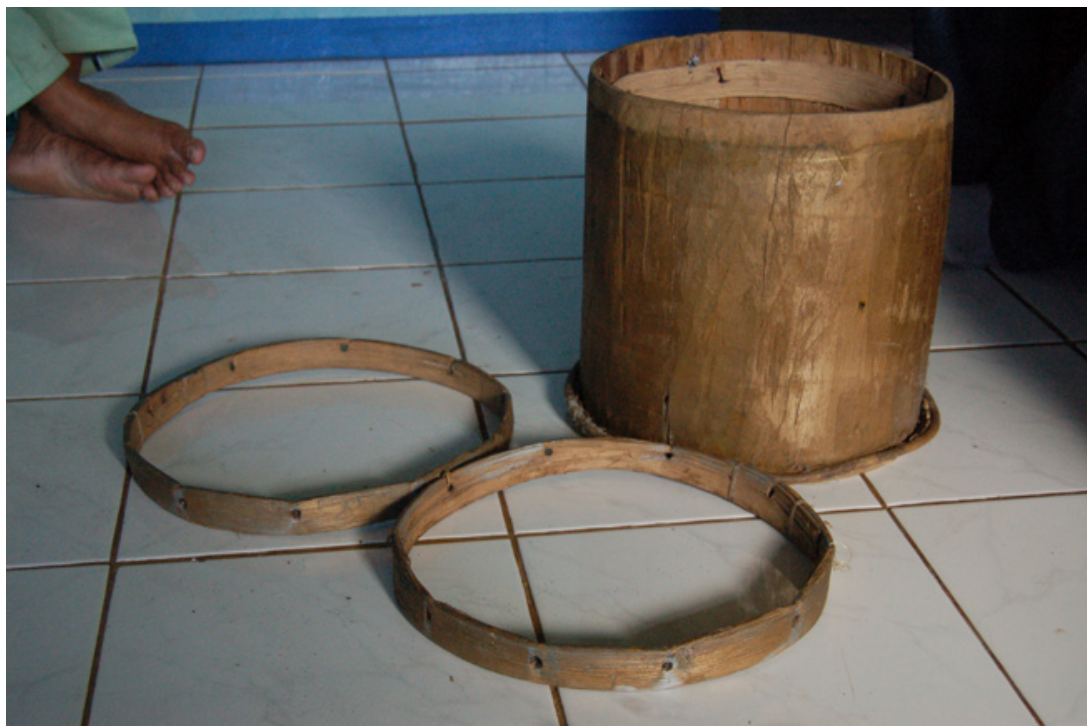

Image 5.5 Old tamburu drum just outside of the Kraton (photo by author, March 2007).

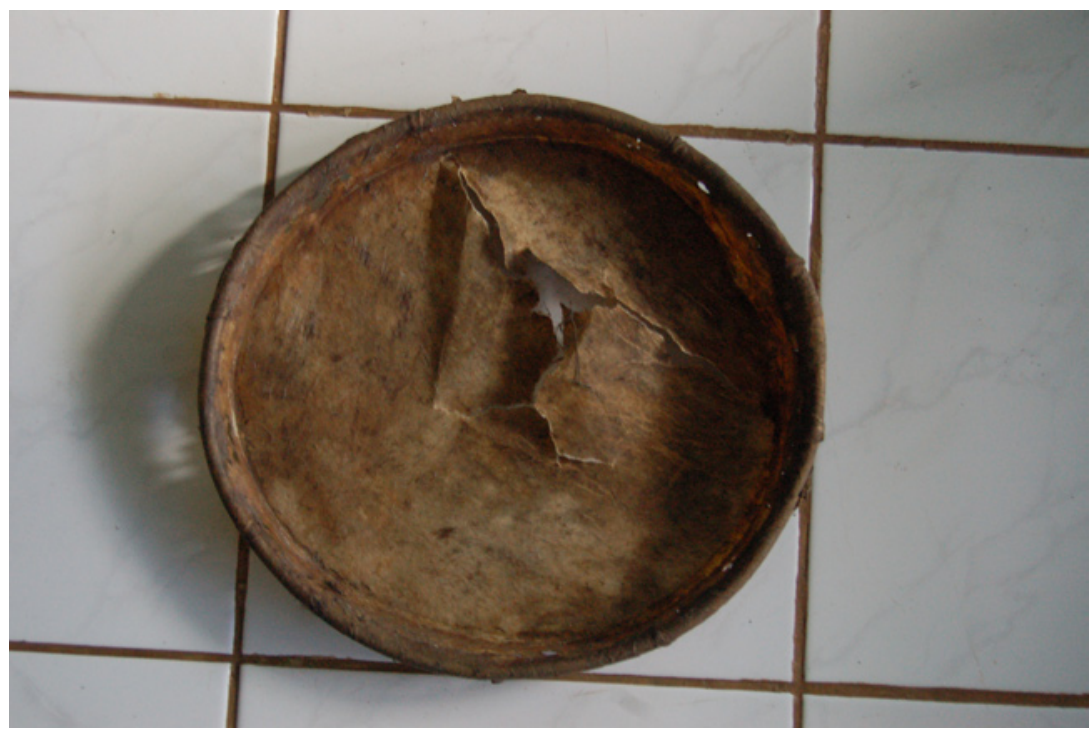

Image 5.6 Membrane of old tamburu drum in image 6 (Photo by author, March 2007). 


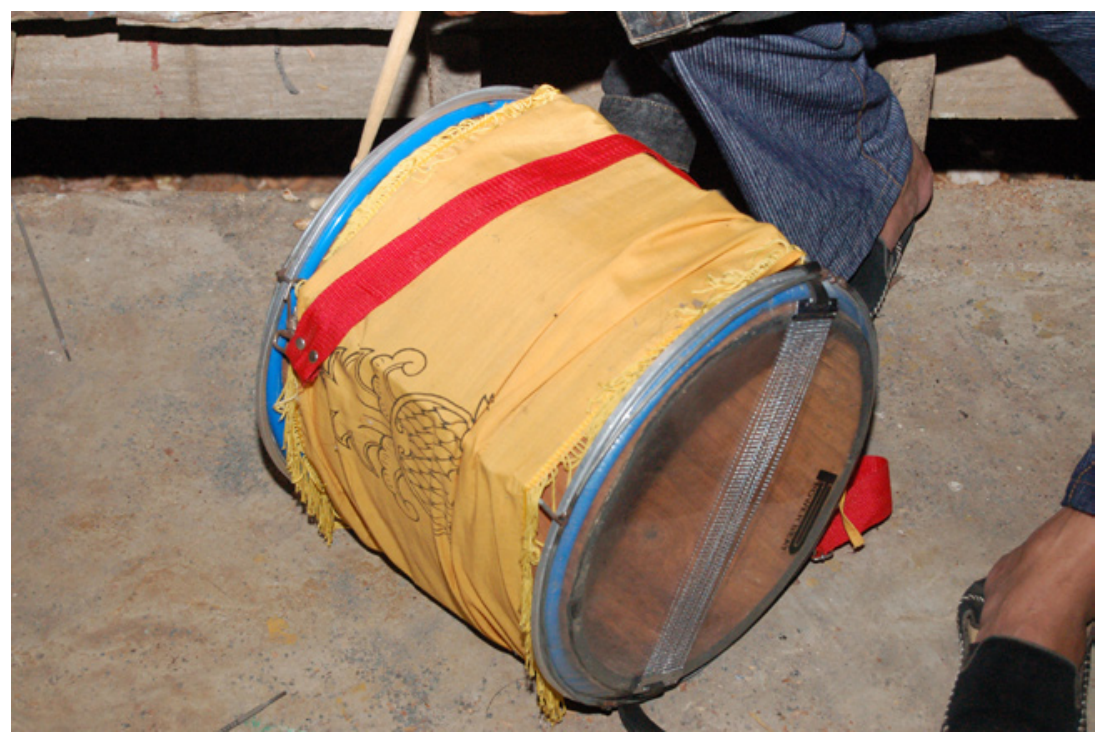

Image 5.7 New tamburu with factory made membranes and snare (photo by author, March 2007).

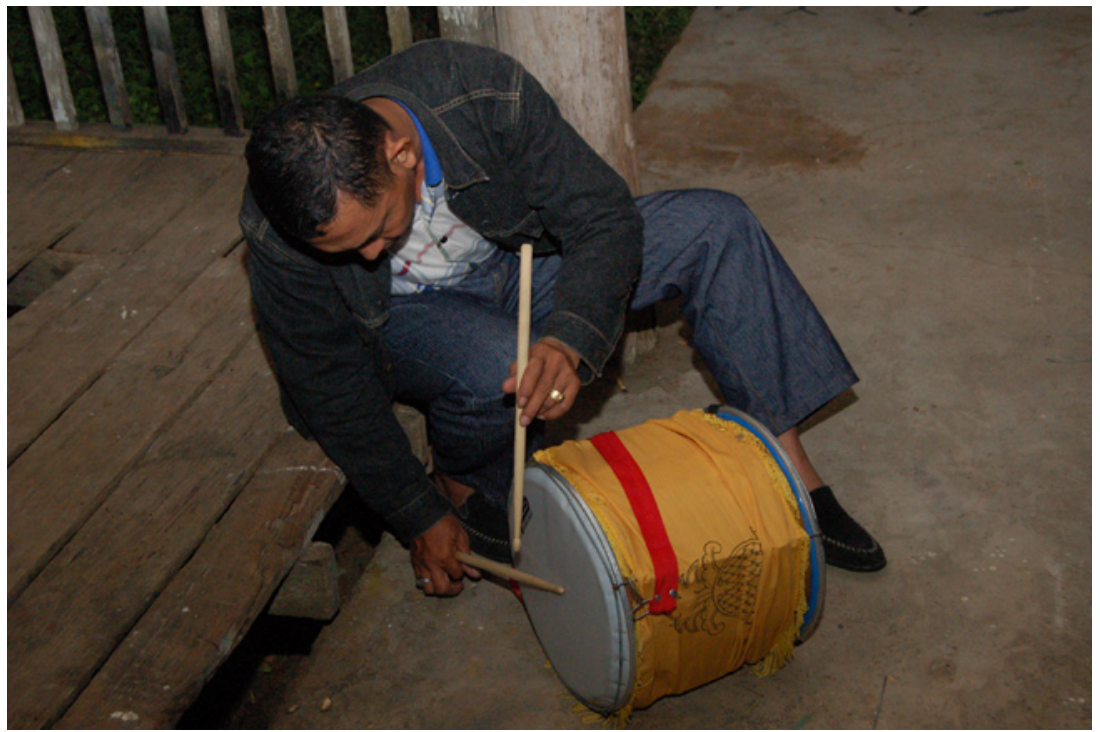

Image 5.8 Tamburu played from the side adorned by the Kraton's pineapple (photo by author, March 2007). 


\section{Conclusion}

The history of Buton has overt musical resonances. The musical instrument most affected by the encounter with the VOC is the military drum called the tamburu. The drum, once adopted from a military practice of a foreign power, was inserted into a ritual that was to uphold local strength. Formal elements of its performance were meticulously copied, ranging from the uniform worn by the tamburu drummers and other kompanjia members, a yellow flag featuring the VOC emblem, and the ranks of the kompanjia itself. Informal musical features were to be found in the European style of playing the drum, the position in which it is placed to play (very similar to that of the military) and the 'roll of the drum' that is so familiar to the Western ear. These drum rhythms appear to have been chosen intentionally and selected for their intimidating and march-like character.

In his writing of Butonese history, Schoorl (1986) describes how the Sultanate's position weakens with the Company gaining power within the region, forbidding its ruler and his subjects from growing or trading spices. New hierarchies are established, which are affirmed by both colonizer and the colonized. Schoorl argues that before and after the implementation of Islam, certain ceremonies prevailed that functioned to express the power of the Sultan and to unite his realm. Instrumental in this were the idea of the Wolio kraton being at its religious-cultural centre (see Ligtvoet 1878) and the Sultan's position as representative of God on earth. With the Company's star rising, however, the status of the palace soon weakened and fewer public appearances and processions by the Sultan had a severe impact on the unity of his realm.

Some type of ceremony or power display may have been in place before the Dutch arrived. It may have included royal bodyguards or soldiers as well. But the Dutch presence altered such processions for ever more, with the Butonese now clearly copying both informal and formal elements of foreign power display. Ironically, one motive for doing so is to affirm the Sultan's power, both in relation to his own people and towards the colonizer, thus ensuring the (political) stability of his realm. He did so exactly by using those elements that publicly represented the powerful Other, its intimidating drum and colourful spectacle figuring prominently. But was it enough to translate European elements into an indigenous setting? Did adding a drum and a Dutch flag to traditional display truly prevent a sharpening distinction between colonizers and colonized? 
As mentioned above, even Van den Berg, otherwise impressed by local musical traditions and especially traditional drumming practices, was somewhat derogatory in his description of the galangi performance. When visiting the northern village of Kalinsusu on 30 October 1940 for an end-of-the-fasting-period celebration, he encountered dancing kompanjia members, referring to them as 'those fading remains of a little group of soldiers from the Company's era' (Van den Berg 1940, 1941). ${ }^{20}$ By that time, the galangi had changed in meaning and character, its use resembling that of today's welcoming dance to meet high-ranking guests. What Van den Berg describes is indigenous practice, but he judges it by colonial standards - referring to its former use and it being just a copy of what it supposedly once was. Importantly, this act of appropriation and copying the colonizer in performance could well trigger more differentiation; because the copy is still deemed inferior to the original by the colonizer. Bhaba would, presumably, see this as a case of 'power-resistance', through which the labelling of the old versus the new, the original versus the imitation, only intensifies and re-establishes such dichotomies in the long run, ultimately weakening, in this case, the Sultan's power. History appears to confirm this fate, as 'self-governing' Buton began losing its power towards 1906, a process that was final with the passing of the last Sultan.

From an instrument of war in VOC times, the tamburu has evolved and is now part of a local welcome dance. In the process, new elements have been added to this once foreign instrument and the musical context in which it is presently embedded. Initially a direct copy, it later would be adorned with the pineapple emblem of Wolio. Its company's spear and flag have survived not only the VOC, but also the colonial apparatus of which both Kaudern and Van den Berg were once representatives. Once a symbol of Dutch might and intimidation, the Butonese now preserve a tradition that is hard to find in the Netherlands today.

\section{References}

Anceaux, J.C. Wolio dictionary: Wolio-English-Indonesian. Dordrecht and Providence: Foris, 1987.

Berg, Engelbertus Johannes van den. 'De viering van den raraja hadji in de Kota Wolio', Tijdschrift voor Indische Taal-, Land-en Volkenkunde 77: 650-66o, 1937.

20 'Die verwaterde overblijfselen uit den Compagniestijd van een groepje van krijgsknechten'. 
'Adatgebruiken in verband met de sultansinstallatie in Boeton', Tijdschrift voor Indische Taal-, Land- en Volkenkunde 79: 469-528, 1939.

_. 'Een rijstfeest in Lawele', Tijdschrift voor Indische Taal-, Land- en Volkenkunde 80: $530-543,1940$.

- 'Keramaian lepas poeasa di Kalensoesoe', Sinar Selebes Selatan 1: 261-262, 1941.

Bhabha, Homi. The location of culture. New York: Routledge. [First published 1994.] 2005.

Boonzajer Flaes, Rob. Bewogen koper. Amsterdam: De Balie, 1993.

Brenner, Miriam Leah. 'Uplifting spirits; An introduction to traditional music and instruments of Sulawesi Tenggara's islands of Buton and Kabaena'. BA thesis, Universiteit Utrecht, Utrecht, n.d.

Cense, Anton Abraham (ed.). 'Mededelingen uit de verslagen van Dr. E.J. van den Berg; Taalambtenaar op Buton 1936-1941', Bijdragen tot de Taal-, Land- en Volkenkunde 110-2: 154-184, 1954.

Evers, Hans-Dieter. 'Traditional trading networks of Southeast Asia', Archipel 35: 89-100, 1988.

Evers, Hans-Dieter and Karl Reinhold Heallquist. 'Traditional trading networks in Southeast Asia', in: Karl Reinhold Heallquist (ed.), Asian trade routes: Continental and maritime, pp. 142-152. Copenhagen: Scandinavian Institute of Asian Studies; London: Curzon Press, 1991.

Fontijne, L. 'Memoire van overgave Boeton'. [Manuscript.] 1949.

Hilarian, Larry Francis. 'The gambus (lutes) of the Malay world', in: José S. Buenconsejo (ed.), A search in Asia for a new theory in music: A symposium organized by the University of the Philippines, Center for Ethnomusicology as the 7 th International Conference of the Asia Pacific Society for Ethnomusicology (APSE), 17-23 February, pp. 455-488. Quezon City, The Philippines: University of Philippines Press. [Conference proceedings.] 2003.

Kaudern, Walter E. Musical instruments in Celebes: Vol. 3: Ethnographical studies in Celebes. Göteborg: Elanders Boktrykeri, 1927.

Kielstra, E.B. 'Het sultanaat van Boeton', Onze Eeuw 8: 452-472, 1908.

Ligtvoet, Albertus. 'Beschrijving en geschiedenis van Boeton', Bijdragen tot de Taal-, Landen Volkenkunde 4-2: 1-112, 1878.

Maceda, Jose. Gongs and bamboos: A panorama of Philippine music instruments. Manila: University of the Philippines Press, 1998.

Madleven, M. et al. 'Nota's adatstaatsinstellingen afdeling Boeton en Laiwoei, Zuid-Celebes 1947-1948'. [Manuscript.] 1947/48.

Martin, Johan Karl Ludwig. Reisen in den Molukken, in Ambon, den Uliassern, Seran (Ceram) und Buru. Leiden: Brill, 1894.

Mekuo, A. Djohan (ed.). 'Ensiklopedi musik dan tari daerah Sulawesi Tenggara'. Kendari. [Manuscript.] 1977/8.

Pigeaud, Th.G. Java in the 14th century. A study in cultural history. The Nägara-Kèrtāgama by Rakawi, prapañca of Majapahit, 1365 A.D., III Translations. 's Gravenhage: Nijhoff. [Translation series KITLV 4-3.] 1960.

Rudyansjah, Tony. 'Umstrittene Identitäten. Hierarchische Beziehungen und Machtdiskurse auf Buton, Südost-Sulawesi', in: Martin Slama (ed.), Konflikte - Mächte - Identitäten. Beiträge zur Sozialanthropologie Südostasiens, pp. 219-237. Vienna: Verlag der Österreichischen Akademie der Wissenschaften, 2009.

Schoorl, Johan Willem (Pim). 'Power, ideology and change in the early state of Buton'. Paper, Fifth Dutch-Indonesian Historical Congress 'State, Trade and Society: Teachers, Preachers and Pressmen', Lage Vuursche, 22-27 June, 1986.

- . 'Het "eeuwige" verbond tussen Buton en de VOC, 1613-1669', in: Harry A. Poeze and Pim Schoorl (eds), Excursies in Celebes, een bundel bij het afscheid van J. Noorduyn als directeur secretaris van het Koninklijk Instituut voor Taal-, Land- en Volkenkunde. Leiden: KITLV Publishing. [Verhandelingen KITLV 147.] 1991.

Sijs, Nicoline van der. 'Vroege dateringen II', Trefwoord 9 (October): 71-73, 1994. 
Stevens, Alan M. and A. Ed. Schmidgall-Tellings. A comprehensive Indonesian-English dictionary. Athens and Ohio: Ohio University Press, 2004.

Tiele, P.A. (ed.). Bouwstoffen voor de geschiedenis der Nederlanders in den Maleischen Archipel. Bewerkt door J.E. Heeres. Vol. 2. 's Gravenhage: Nijhoff. Three volumes, 1886.

Zahari, A. Mulku. Sejarah dan adat Fiy Darul Butuni (Buton). Jakarta: Departemen Pendidikan dan Kebudayaan. Three volumes, 1977.

. 'Sejarah masuknya Islam di Buton dan perkembangannya'. Bau Bau. [Manuscript.] 1980. 